\title{
The Singer as Individual: Pop Singers, Music and Political Propaganda in Contemporary Maltese Electoral Campaigns
}

\section{PHILIP CIANTAR}

Various genres and styles of popular music are employed in strategies of political propaganda not only to promulgate a political message and make it sound persuasive but also to bring people from various strata of society together in support of an ideological and/or propagandistic objective. Research in this area highlights the use of music to influence people's actions and "achieve organizational cohesion" for both ideological and propagandistic purposes. ${ }^{1}$ Popular music in general, and pop music in particular, occupies a strong place in all this due to its wide appeal. ${ }^{2}$ One notes the central role of the individual musician not only as a performer with a message embedded in his or her music (whether a song or an instrumental piece) but also as an individual member of society with his or her own life history, upbringing, social background, political values, and affiliations. For the audience, access to such information is essential as it provides them with ample opportunity to perceive a musical performance in the context of various personal and collective agendas, these being both covert and overt. The scrutiny of a performer as an individual also sheds light on how performers see themselves in their own culture and how that perception is manipulated by an array of events and interests. All this adds value to the understanding of a process that leads towards a more "complete" perception of a song, for instance, and what lies behind it.

The aim of this article is twofold: firstly, it will throw light on the role of pop music in Malta as a tool of political propaganda in contemporary electoral campaigns and the ever-increasing focus of propagandists on individual local pop singers; secondly, it will scrutinize the benefits these propagandists anticipate from their emphasis on the individuality of pop singers in their attempt to attain the support of the masses. Through the discussion of a number of examples, I will argue that, in the context of masses sharing the same socio-cultural and political knowledge, a propagandistic message not only exploits the music and the lyrics of a political song but also the very presence, individualization and participation of the singer in that same song. In such a scenario, the individual singer becomes a message in itself-a message that links to personal life histories in order to attain a higher degree of mass appeal. It is the kind of history that brings forth for the scrutiny of the masses the singer's past and any personal political stands that might have been kindled by current circumstances. Who these singers are and what political backgrounds they come from are part of the message that their songs intend to convey, sometimes even more strongly than the message contained in the musical and lyrical components of the song itself. This places more bearing

\footnotetext{
${ }^{1}$ Serge R. Denisoff, "Folk Music and the American Left: A Generational-Ideological Comparison," The British Fournal of Sociology 20, no. 4 (1969): 428.

${ }^{2}$ Pop music is understood here as a genre originating in the 1950 s that embraces various styles and is "connected with the development of new media and music technologies, and with the growth of large-scale recording and broadcasting industries," according to Richard Middleton in Studying Popular Music (Milton Keynes: Open University Press, 1990), 101.
} 
on the existing presentation that any performance puts on the personal lives of pop musicians. In this regard, Nicola Dibben notes that the musical output of pop musicians is perceived as though it is the expression of biographical events, the public revelation of the inner life of the performer. ${ }^{3}$ This observation matches Philip Auslander's claim that musicians are involved both in the playing of music as well as in the playing of various roles. Such roles depend on the amalgamation of "three signifieds" that Auslander identifies in performance: the performer as a real person with the desire to perform and willingness to express his or her own ideas through popular music; the performance persona of the singer as "self-presentation" projected through various means, including makeup, facial expressions, and gestures; and the character which may be described as the character of the song, implying the lyricist's voice and/or the subject matter of the song. ${ }^{4}$

The present article will commence by presenting a short survey of the employment of music in contemporary Maltese electoral campaigning, with the intention of highlighting the ever-increasing emphasis on local individual singers to identify themselves politically through their involvement in (or absence from) political campaign songs. In a strongly bipartisan political system such as that in Malta, the political affiliation of some local pop singers is crucial, as it may open up or restrain opportunities in the entertainment sector as well as increase or decrease access to governmental power, if one considers the fact that "performance is a means by which so many things can be achieved and which cannot be obtained otherwise in normal life circumstances." All this is intrinsically interwoven with issues of personal, social, and economic security, these being at the heart of all decisions involving performers and career prospects. The second section will then analyze the presence of these individual pop singers in locally-produced election song video productions. This section will shed light on the individual participation of these singers and how this is synthesized with public knowledge regarding the singers' lives and/or past political affiliations. The last section will provide further evaluation of the productions mentioned above through the application of more relevant theories. Some of the observations introduced in this and the previous section were communicated to me by colleagues and friends who had kindly agreed to watch the song videos referred to in this article. ${ }^{6}$ Additional comments were articulated by people I met with in everyday life, and others were expressed both online and in the local Maltese media.

\section{Music and Maltese Political Campaigning in a Nutshell}

Malta, officially known as the Republic of Malta, is a Southern European island-nation situated in the center of the Mediterranean (see Figure 1). The country covers just over 316 square kilometers in land area, making it one of the world's smallest states. With a population of about 400,000 inhabitants, Malta is also one of the most densely populated countries worldwide. The parliamentary system and public administration are modeled on the Westminster system. Malta's House of Representatives in the current legislature is made up of 69 Members of Parliament. A political party obtaining the majority of votes in a general election will also have the majority of seats in parliament. The President of Malta, whose role as

\footnotetext{
${ }^{3}$ Nicola Dibben, "Vocal Performance and the Projection of Emotional Authenticity," in The Ashgate Research Companion to Popular Musicology, ed. Derek B. Scott (Farnham: Ashgate, 2009), 331.

${ }^{4}$ Philip Auslander, "Musical Persona: The Physical Performance of Popular Music," in The Ashgate Research Companion to Popular Musicology, 314.

${ }^{5}$ Philip Ciantar, The Ma'lüf in Contemporary Libya: An Arab Andalusian Musical Tradition (Farnham: Ashgate, 2012 ), 98.

${ }^{6} \mathrm{I}$ am most grateful for comments I received on these song videos from Gordon Zammit, Mariella Cassar-Cordina, Kevin Mizzi, Tania Ciantar, and Albert Pace.
} 
head of state is mainly ceremonial, is appointed for a five-year term by a resolution of the House of Representatives carried by a simple majority.

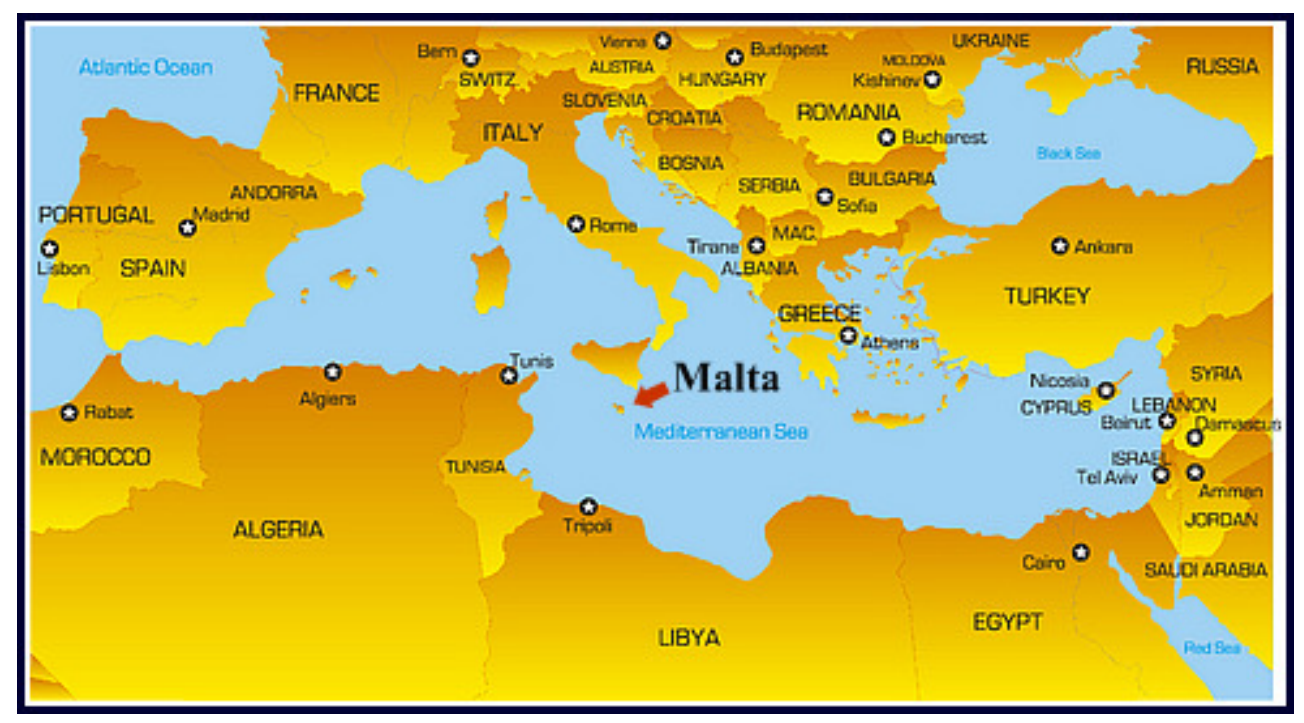

Figure 1: Malta in the Mediterranean. ${ }^{7}$

Malta's main political parties are the Nationalist Party (hereafter referred to as the PN), which is a Christian democratic party, and the Labour Party (hereafter referred to as the PL), a social democratic party. ${ }^{8}$ At the time of writing this article, the PL is in government, having won the general election of March 9, 2013. There are a number of smaller political parties in Malta; however, these have no parliamentary representation and, therefore, Malta's political scene is dominated by the two main parties. The fact worth mentioning here is that both parties each own a radio and television station and exploit these through a schedule containing both entertainment and political programs, the latter aimed at communicating the party's voice. Throughout the years, the two parties have employed popular music both to promulgate their ideology and as a tool of political propaganda during election campaigns. In the 1970s, for example, the PL employed a style of Maltese folk singing known as ghana (pronounced "āna") to project support and sympathy for "the working class," mainly understood in this context as the blue-collar working class. During this time ghana singers "sang at Labour party rallies" 9 and were even sent abroad by the said party in government to participate in folk music festivals. A landmark development in the use of pop music in Maltese politics goes back to 1982, when the first Maltese rock-opera Gensna (“Our Nation”) was produced by the PL. Gensna recounts the nation's most salient historical milestones and the hardships endured by the Maltese as they struggled for their country's freedom from foreign domination. For that production, the PL brought together a number of renowned Maltese pop singers of the 1980s in a production considered, at that time, as a breakthrough in local musical productions employing the Maltese

\footnotetext{
${ }^{7}$ Fig. 1 is reproduced from http://www.maltabulb.com/map-of-the-mediterranean.html (Accessed September 20, 2014).

${ }^{8}$ At this stage, it is important to note that during an Extraordinary General Conference held in November 2008, it was decided that the Party's official name would be Partit Laburista (PL) instead of its former name Malta Labour Party (MLP). This explains the use of MLP instead of PL in some of the quotes cited in this paper.

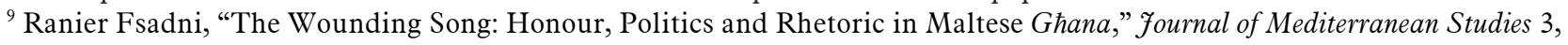
no. 2 (1993): 341.
} 
language. ${ }^{10}$ Some of the songs in that musical are still sung today and are performed during mass political meetings held by the same party; indeed, this rock-opera became synonymous with the PL, with the participating singers featured at that time attaining considerable fame and visibility throughout the years that followed. ${ }^{11}$

Over the years, imported pop music played an important role in Malta's political campaigns. For instance, the 1987 general election saw the PN inviting foreign pop singers, such as the Italian singer Marcella Bella, to perform during its mass electoral activities. Such foreign participation was forged by the $\mathrm{PN}$ as a symbol of the party's plea and struggle for more democracy in the country and the international support that it was gaining for that purpose. In the same campaign, the PN chose as its campaign song "The Final Countdown," a song released in 1986 by the Swedish band Europe. This was to promote the PN's campaign message that after sixteen years of Labour governance Malta needed an imminent change in political direction, and that the election had to bring the much desired change.

The 1987 electoral campaign, as designed by the PN, triggered the employment of more foreign pop songs in subsequent electoral campaigns. The 1996 electoral campaign, for example, saw the PL employing Robert Miles's "Children," released a year before in his album "Dreamland," as its campaign song. ${ }^{12}$ That was followed by the PN in 1998 adopting Modern Talking's "We Take the Chance" for that year's general election. At this stage, it is worth noting that "We Take the Chance" samples "The Final Countdown" in its grandiose introduction. As Goodwin rightly notes, in this sense sampling is "used to invoke history" while "the 'quoting' of sounds and styles acts to historicize contemporary culture." 13 The PN's intention was to evoke the 1987 electoral victory that had initiated Malta's process of joining the European Union and, at the same time, to reaffirm its political commitment to resuming the process following the freezing of the application by the PL government between 1996 and 1998. This was a historical opportunity that the electorate should not miss at that time. Referring to the use of the "Final Countdown," the Malta Independent wrote the following on the eve of Malta's accession into the EU in 2004, another historical event in Malta's political history:

Looking back, that song carried with it another twist, a sort of anticipation of what was to come in future years. Because that song was recorded by a group called Europe, and that election victory for the Nationalist Party was the first step towards Malta's accession to the European Union. ${ }^{14}$

More examples of foreign songs being employed in subsequent electoral campaigns include the 1988 chart hit "The Only Way Is Up," performed by Yazz and the Plastic Population, which in the 2008 general

\footnotetext{
${ }^{10}$ The music of "Ġensna" was composed by Paul Abela to words by Ray Mahoney (for an extract from the original version, see http://www.youtube.com/watch?v=w8QF69WgBtw). A concert version of the same work was presented in March and April 2009 (for an extract from the 2009 concert version, see http://www.youtube.com/watch?v=xW3QWo7WBSs). For more information about "Ġensna" and its concert version, see http://www.timesofmalta.com/articles/view/20090321/life/gensna-anations-music.249716 (All sites accessed October 21, 2014).

${ }^{11}$ A more contemporary version of this rock-opera was presented in the spring of 2014 as part of the $35^{\text {th }}$ anniversary of Malta's Freedom Day, which marks the closure of the British military base in Malta, during an event marking national unity rather than political partisanship (for an extract from this version, see http://www.youtube.com/watch?v=1NwBMcFmdNo). The 2014 production has irritated some veteran singers who had taken part in all past performances of "Ġensna" but were not invited this time (see, for example, http://www.maltatoday.com.mt/arts/music/36704/labour_icon_irate_at_gensna_rebuff\#.U8Y95ZSSxvk) (Accessed November 11, 2014).

${ }^{12}$ See http://www.youtube.com/watch?v=Y42bm0qGnCM (Accessed August 15, 2014).

${ }^{13}$ Andrew Goodwin, "Popular Music and Postmodern Theory," Cultural Studies 5, no. 2 (1991): 175.

${ }^{14}$ As quoted by Teodor Reljic, "The Music of Politics," Malta Today, January 29, 2012, accessed June 1, 2015, http://www.maltatoday.com.mt/arts/music/15567/the-music-of-politics-20120128\#.U8Vd4ZSSxvk.
} 
election had its chorus altered slightly by the Labour campaign from the "Only way is up, baby" to "The only way is up, Labour." 15 More recently in the 2013 general election, we find the PL using "New Tomorrow" by the band A Friend in London as one of its campaign songs, with the same group being invited by that party to perform during the days leading up to election day. ${ }^{16}$ In parallel with this, one also notes the increasing role of local singers with their personal political affiliations being brought to the attention of the general public and all the evaluation that this has generated.

\section{A Spotlight on Individual Singers}

The active role of individual singers in Maltese political propaganda gained momentum during the 2003 EU referendum campaign. While the PN campaigned in favor of full membership in the EU, the PL sought public support for close relations with the EU in the form of partnership but without the commitments of full membership. The PN's campaign fostered a positive feeling towards change against the negative message of the PL's campaign that stressed the disadvantages of full membership for Malta. To further strengthen a positive feeling towards change, the PN created and launched the song "Nghidu IVA" ("We say Yes"). In a 2004 publication, Joe Saliba, then General Secretary of the PN, wrote the following:

The song not only had an uplifting and captivating melody, but, through its lyrics, it also reinforced the notion of moving forward together... The objective at this stage was to make sure that the electorate understood and identified with what the song was communicating, given that, eventually, all the key phrases incorporated within the lyrics were to be used on the billboards throughout the campaign. Thus, the public was already familiar with the slogans being used as the campaign progressed. ${ }^{17}$

Both parties mobilized local singers to perform respective referendum campaign songs, one in favor of "partnership" and the other in support of "full membership." A striking occurrence during that campaign was when some singers known as staunch Labourites shifted their allegiance to the PN, marking their support for full membership by participating in the video of PN's song "Nghidu Iva." Some of these singers were known for having relatives in PL's executive committee and, therefore, were putatively attributed with a "natural affiliation," while others were known for beginning their artistic careers with frequent appearances and exposure on the party's TV and radio stations. According to Saliba, the fact that people typically associated "with the MLP were endorsing the 'Yes' camp message, further reinforced the concept of a national, rather than a partisan, issue." 18

One of the singers who featured in the PN's "Yes" song and who had strong affiliation to Labour was Chiara Siracusa (b. 1976), known by her mononym Chiara. Hailing from Senglea, one of the Three Cities considered as Labour strongholds, Chiara represented Malta three times in the Eurovision Song Contest (1998, 2005, and 2009), and placed second in 2005, Malta's most successful entry since the country's first participation in $1971 .{ }^{19}$ Her late father was a past member of the Malta Labour Party

\footnotetext{
${ }^{15}$ See https://www.youtube.com/watch?v=rYV2y-P-SpA. (Accessed March 3, 2015.)

${ }^{16}$ See http://www.youtube.com/watch?v=fEVLQfX2R-0. (Accessed February 5, 2015.)

${ }^{17}$ Joe Saliba, "Referendum and General Elections in Malta," in Election Time: The European Yearbook of Political Campaigning

2003 (Austria: European Association of Political Consultants, 2004), 100-122.

${ }^{18}$ Ibid., 112.

${ }^{19}$ See Chiara's participation in the 1998 (https://www.youtube.com/watch?v=jZFCq_d57o8), 2005

(https://www.youtube.com/watch?v=TABFvqzR1-M), and 2009 (https://www.youtube.com/watch?v=RHJzU7quWh0)
} 
executive committee, so she was known as coming from a Labour family background. She was regularly featured on Super One Radio and TV (Labour's radio and TV stations) before she broke her political allegiance with Labour, mostly because of her participation in the "Yes" EU referendum video song. ${ }^{20}$ Her successful singing career and three appearances as Malta's representative in Eurovision brought her into the limelight with the local media, triggering public intrusion even in her own personal life. ${ }^{21}$ The other singer who, like Chiara, seized the attention of Labour supporters for his appearance in the PN referendum song was Fabrizio Faniello (b. 1981), publicly described by the then Head of Programs of Labour's radio station as "a product of Super One." Fabrizio represented Malta twice in the Eurovision Song Contest (2001 and 2006), ${ }^{22}$ bringing him wide coverage in the local media. ${ }^{23}$

Both Chiara and Fabrizio, together with some of the other singers taking part in the "Yes" song, were also invited by the PL to sing in the Partnership song which Super One TV was planning to produce for the same campaign. However, that invitation was turned down by all those participating singers. This made news in the local press, especially after rumors that singers taking part in the "Yes" song were being pressured to sing in PL's production also. The Times of Malta, for instance, quotes one unnamed singer of the "Iva" song claiming that Labour officials were sending a clear message, whether directly or indirectly, to those that sang in the PN song that this was a betrayal of the Labour Party ${ }^{24}$ : "I know of singers who received phone calls from Labour supporters accusing them of betraying the party." ${ }^{25}$ Another singer contacted by the same newspaper showed preoccupation with this quandary, claiming that, "People from one party tell us we will lose credibility if we sing in both songs and the others are hinting that their party will stop supporting us if we turn them down." ${ }^{26}$ When reporting this rumor, MaltaToday looked at the reactions of some of these singers to PL's call to participate in the "Partnership" song. For instance, when referring to Chiara, the paper reports the following:

For one singer whose Senglea roots had her billed as a Super One favourite, EU accession seemed to have transcended partisan pique when 1998 Eurovision third runner-up Chiara featured in the YES camp's song. Chiara however refused to comment when MaltaToday asked her whether there had been any pressure from Super One TV to join the NO song crew. She also refused to divulge the reasons for participating in the YES song. ${ }^{27}$

Fabrizio Faniello's reaction was also non-committal and he avoided expressing a definite view on the matter:

\footnotetext{
Eurovision Song Contests, accessed May 30, 2015.

${ }^{20}$ The Labour Party's One Radio and One TV were previously known as Super One Radio and Super One TV. For the sake of consistency I refer to both with the name they were known with at that time.

${ }^{21}$ For an interview with Chiara in the local press see http://www.timesofmalta.com/articles/view/20090315/interview/lifemakes-you-cynical.248857. See also an interview with Chiara (with English subtitles) on Xarabank, a popular weekly TV programme on TVM (Malta's National TV), in which she says how hurt she feels when ridiculed for her overweight figure https://www.youtube.com/watch?v=w9TbinGzgFU. (Accessed April 17, 2015.)

${ }^{22}$ See Fabrizio's participation in the 2001 (https://www.youtube.com/watch?v= cYITo2AH0A) and 2006 (https://www.youtube.com/watch?v=kiORqJIala8) Eurovision Song Contests, accessed January 15, 2015.

${ }^{23}$ See, for example, http://www.independent.com.mt/articles/2007-07-14/local-news/Another-Summer-night!-176444. (Accessed November 11, 2014.)

${ }^{24}$ This was recently reaffirmed in a personal communication by a former Super One journalist who preferred to remain anonymous. However, at that time these rumours were denied by the Labour Party through one of its officials. See Herman Grech, "Singing to Parties' Tunes Creates Dilemma for Performers," The Times of Malta, February 1, 2003, accessed June 2, 2015, http://www.timesofmalta.com/articles/view/20030201/local/singing-to-parties-tunes-creates-dilemma-forperformers.157713.

${ }^{25}$ Grech, "Singing to Parties' Tunes."

${ }^{26}$ Ibid.

${ }^{27}$ Matthew Vella, "IVA Singers Asked to Sing 'No to Europe'," MaltaToday, February 2, $2003,1$.
} 
2001 Malta Song for Europe winner Fabrizio Faniello was dubbed to have accepted both invitations from both sides, but told MaltaToday his management abroad were still considering Super One's invitation. Faniello has already contributed to the YES camp's EU song. ${ }^{28}$

Whatever the case and the intentions behind it, there was a covert agreement amongst Labour singers taking part in the "IVA" song that one cannot fool "people by singing for such an issue for two opposed polarities." 29

Figure 2: Video for "Nghidu Iva" ("We say Yes")

View at: http://dx.doi.org/10.3998/mp.9460447.0010.106

The video of PN's EU referendum song featured renowned local singers coming from the Labour camp standing side by side and holding hands with their counterparts from the PN, all reiterating the chorus that their choice in favor of full EU membership was a choice for a better Malta:

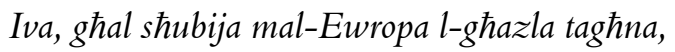

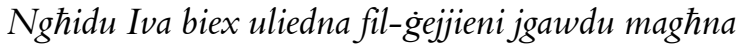

Iva: ghalina, ghal uliedna, ghal pajjiżna

Nghidu Iva.

Yes, our choice is for membership with Europe

We say Yes, so that in the future our children will benefit with us

Yes: for us, for our children, for our country

We say Yes. ${ }^{30}$

Such collectivity comprised children and TV personalities as well as other people of all ages coming from different strata of Maltese society, all united in a cohesive group in support of a political goal. This provided the right scenario for valuing an individual singer vis-à-vis the collective pronouncement of the choir. Singers known for their Labour support were positioned at the front in the video, and were visibly encouraged by their Nationalist counterparts to move forward and draw attention to themselves in the verse.

The "IVA" song had a ballad style with verses mostly divided into solos, duos and trios, with individual singers leaving the group and moving forward in an attempt to highlight their presence in the video and, therefore, their significant individuality as an affirmation of political conviction. Informants have described the choreography as simple and soothing yet highly effective, perfectly matching the feeling of the music and the intended message. The song's smooth texture and catchy tune conveyed a serene context through which the Maltese could think intelligibly about their own future-a song ambience reinforced by the gentle sideways swaying of all the participating singers and the use of dim lighting evoking serenity. Throughout the video, viewers are made to believe that the collective statement pronounced in the chorus is being reaffirmed and expanded on by the real persons who have distanced themselves from partisan politics or familiar party affiliations for the good of the country, as advocated in the verse. This is supported by a range of artistic techniques that make up the performance persona, such as the effective employment of a spotlight beaming on the singers moving to the fore, and the

\footnotetext{
${ }^{28}$ Ibid., 7.

${ }^{29}$ Ibid.

${ }^{30}$ Author's free translation.
} 
pronouncement of the character which, in this case, is made up of the subject matter of the song as construed by the propaganda machine. The spotlighting of individual singers in this video builds on the fact that "in performance singers not only are spotlighted, but also have the principle role in the creation of mood and meaning." 31

PN's song video emphasized social cohesion and inclusivity-a kind of cohesion that was as social and political as it was musical. ${ }^{32}$ The viewer is made to believe that with Malta in the EU, the opportunities would be boundless and, therefore, social cohesion and solidarity were of utmost importance at this decisive historic moment. While for the PN this meant a huge political accomplishment in a stronglyfought referendum campaign in favor of full EU membership, for Labour diehards such a political shift on the part of these singers signified disloyalty to the party, as some Labour supporters have asserted to me. Nevertheless, politically viewed, the presence of Labour singers in the PN video was widely understood as evidence of the seemingly extensive support in favor of full membership—a kind of support that attained further impetus a few days after the launch of the same video when the then Maltese Prime Minister addressed a press conference with representatives of the constituted bodies (e.g., the workers' unions, employers' union, Chamber of Commerce, etc.) sitting at the rear, all signaling their unions' backing of full membership. The referendum result in favor of Malta's accession was then reaffirmed by the PN's victory in a general election held a few months later.

The same song style was later adopted by the PN in the 2008 and 2013 general election songs as a kind of reminder of this historical landmark in Malta's political history. Some of the singers featured in the EU video song appeared again in the 2008 PN campaign song, which employed the same style not only to remind the electorate of the PL's opposition to full membership, but also to show that the PN still maintained the support it had gained during the EU referendum. That was mainly conveyed through the presence in the song video of the same individual Labour-leaning singers featured in the EU song video, such as Chiara and Fabrizio, stating the message, itself an echo of the 2003 PN referendum song as much as the presence of the same singers, that "Iva-Flimkien Kollox Possibli" ("Yes-Everything is Possible Together") (see Figure 3). MaltaToday had the following observations to make on this video song and its participants:

The tell-tale signs, politically, are that the PN is intent on rekindling the glory of their European victory in 2003 ... the return of the triumphalist 'IVA' affirmation in the PN slogan; the symbolism of 8 March. Electorally, it's all about "peace of mind" and "security"contrasted with the fearful prospect of "change" ... Again, as in 2003, a star-studded line-up of daytime TV presenters, musical nobodies and Eurovision heroes and heroines are supplicating you to vote for the PN. The video's cornice is soft misty border, making everything look like a dream sequence from a soap opera. ${ }^{33}$

The first singer featured in both this and the 2003 song video was Chiara, followed soon after by Fabrizio. As with the 2003 song, there was a feeling of annoyance about this amongst Labour supporters; perhaps much more this time, as this was a purely partisan campaign and not a national referendum. ${ }^{34}$ Comments

\footnotetext{
${ }^{31}$ David Horn, "Singer," in Performance and Production, vol. 2 of Continuum Encyclopedia of Popular Music of the World, ed. John Shepherd et al (London: Continuum, 2003), 112.

${ }^{32}$ The EU referendum result, which favored the PN's quest for full-membership, was turned down by Labour who insisted that there was no majority in favor as the majority of voters either invalidated their vote, voted "no," or abstained from voting. For the PL, accession could only be confirmed by a general election which was eventually held three months after the referendum and won by the PN. As a result, Malta joined the EU on May 1, 2004.

${ }^{33}$ Matthew Vella, "What's Noel Gallagher doing with the PN?" MaltaToday, February 10, 2008, 17.

${ }^{34}$ From personal communication with a former Super One journalist who preferred to remain anonymous.
} 
about this video on social media were varied and included sour-tasting expressions from Labour-leaning commentators, such as:

Ma hasbux ghaxdahlu il-Chiara ha jirbhu bhal ma resqet lejn rebha tal-Eurovision hux? U Faniello, il min hasseb ha jdawwar b'dik il-harsa tieghu? [sic] $]^{35}$

Hope they didn't think that because they included Chiara they will win as when she got near to the Eurovision victory. And Faniello, whom did he think he will persuade with his stare? ${ }^{36}$

The sense of support, this time in favor of the PN, had its roots in the strongly-manifested support of the 2003 referendum song. ${ }^{37}$ Both songs, as some viewers remarked to me, accentuate repetition, inviting people to sing along as in a national anthem. In both songs, the individual Maltese becomes part of something much greater, either the European Union in the EU song, or a united future with the promise of prosperity for everybody in the 2008 campaign song. In this sense, the music and the visuals that accompany it have the capacity to evoke images from the past that, when reinterpreted and perhaps amalgamated with current political discourse, shape visions for the future.

Figure 3: Video for "Iva-Flimkien Kollox Possibli" ("Yes-Everything is Possible Together")

View at: $\underline{\text { http://dx.doi.org/10.3998/mp.9460447.0010.106 }}$

Most of the singers participating in the referendum and the 2008 PN song did not feature in PN's 2013 electoral campaign song. In fact, a commentator on the social media asked: "Where are the IVA singers?"38 Electoral surveys consistently anticipated a landslide victory for Labour, a prediction that was eventually fulfilled. The PN was losing most of its popular support, with some of its MPs and supporters openly leaning towards Labour. On the other hand, following its defeat in 2008, the PL had undergone a thorough restructuring of the party in an attempt to project itself as more inclusive and, therefore, as the natural place for moderates and progressives. This led some of the PN singers featured in the above videos to distance themselves from their 'own' party and even shift allegiance to Labour.

Even though the 2013 PN electoral song adopted the same techniques as the referendum and 2008 electoral songs in an attempt to evoke the political controversies of the past both musically and visually, the absence of renowned singers previously featured in the above song videos, Nationalist and Labourite alike, was in itself a strong signifier of a drop in support for PN. This should be understood in the context of a strongly-fought electoral campaign wherein everything became a signifier, whether the presence or absence of singers in a political song or the time taken talking to a candidate of one party during a home visit compared to the time taken in the company of an opposing candidate. Singers known for their Labour affiliation who had featured in PN's referendum and 2008 songs did not take part in this video, their absence signifying possible reversion to their original party.

The 2013 electoral campaign motto of the PN was "Futur Fis-Sod: Xogћol, Saћћa, Edukazzjoni” (“A Stable Future: Work, Health and Education") (see Figure 4) while that of the PL was "Malta Taghna

\footnotetext{
${ }^{35}$ Reproduced from https://www.youtube.com/all comments?lc=vG2II7QROK8tiVbJXi7skoOKFN7oZQZmD8Qh2JAmHOU\&v=YLv9oQw41Bc (Accessed May 12, 2015).

${ }^{36}$ Author's translation.

${ }^{37}$ This was also noted in a report on this song by the Times of Malta, accessed March 10, 2015, http://www.timesofmalta.com/articles/view/20130113/local/pn-launches-campaign-song.453017.

${ }^{38}$ For example, see http://www.timesofmalta.com/articles/view/20130113/local/pn-launches-campaign-song.453017. (Accessed January 21, 2015.)
} 
Lkoll” ("Malta for All”) (see Figure 5). ${ }^{39}$ Labour's campaign song for the March 2013 election was modeled on Barack Obama's 2008 presidential campaign song "We Are the Ones" "40 with "Taghna Lkoll" ("for all") substituted for the repeated words "Obama." The song video included individuals from different spheres of Maltese society endorsing Labour and its leader. The same video was representative of Maltese society at large, with scenes of Maltese ghana guitar players symbolizing the working class and people of all ages and professions reinforcing the "Malta for All" slogan. Regarding the element of inclusivity in this song, Bartolo observes the following:

This song consisted mainly of an expression of aspirations of Maltese society, stated by persons and groups typical of current Maltese society, who assumed the viewer/listener as 'one of us', including family scenes, and physical contact among groups. The content was full of modern aspirations such as social justice, meritocracy, and a clean environment; 'I wish that my children will be brought up in a society where what counts is what you know rather than whom you know' ('Jien nixtieq li wliedi jitrabbew fsocjetà fejn jghodd dak li taf u mhux lil min taf')... Moreover, the PL song included many statements making direct links to the audience, and to 'Joseph' [the Party's leader] being the person who understood everyone and who could bring about national unity ... ${ }^{41}$

The Obama style of electoral campaigning, accentuating the new media communication strategy, was very evident in the Labour Party's electoral strategy and, by extension, in the song video as well. ${ }^{42}$ The video included Malta's 1993 representative in the Eurovision Song Contest, William Mangion, ${ }^{43}$ who had featured very prominently in the past PN campaign songs mentioned above. ${ }^{44}$ Mangion's shift of allegiance to Labour sent a strong message, perhaps even stronger than the one he pronounced in the Labour video itself and the interview he gave about distancing himself from the PN to iNewsmalta. When reporting this, the same online newspaper expressed the surprise of so many Maltese viewers when watching Mangion singing in the PL's campaign song:

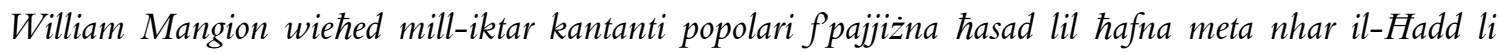

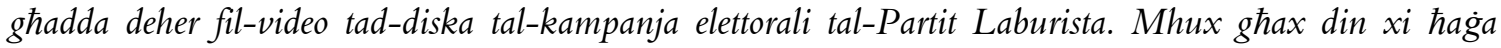

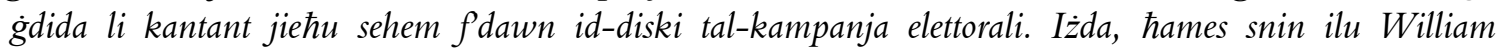
Mangion kien qieghed ikanta fid-diska tal-Partit Nazzjonalista, Flimkien Kollox Possibbli.

William Mangion, one of the most popular singers in our country, took many by surprise when last Sunday he appeared in the song video of the Labour Party electoral campaign. Not because it is something new for singers to participate in such electoral campaign songs, but because five years ago William Mangion was singing in the Nationalist Party song, YesEverything is Possible Together. ${ }^{45}$

\footnotetext{
${ }^{39}$ For reactions to both songs, see Kristina Chetcuti, "It's My Party and I'll Sing if I Want To: Election Tunes Rubbished by Music Experts," The Times of Malta, February 28, 2003, accessed November 11, 2014,

http://www.timesofmalta.com/articles/view/20130228/local/It-s-my-party-and-I-ll-sing-if-I-want-to.459461.

${ }^{40}$ See song video for "We Are the Ones" at http://www.youtube.com/watch?v=ghSJsEVf0pU.

${ }^{41}$ Paul A. Bartolo, Winning People's Hearts: How Social Inclusion and Exclusion Informed the 2013 Malta General Election Campaign (Malta: Malta University Publishing, 2015), 136.

${ }^{42}$ For a comprehensive discussion regarding the use of the new media communication strategy employed in Obama's 2008 electoral campaign, see Ekaterina Alexandrova, "Using Media Effectively: An Analysis of Barack Obama's Election Campaign Aimed at Young Americans" (MA thesis, Fordham University, 2010).

${ }^{43}$ See William Mangion's participation in the 1993 Eurovision Song Contest at https://www.youtube.com/watch?v=tlnBdQWYuQs. (Accessed October 15, 2014.)

${ }^{44}$ For further reading on the PL's music video, see http://www.maltatoday.com.mt/news/elections2013/24121/labour-releasesofficial-music-video-20130122\#.VW8t2tKqqko. (Accessed February 13, 2015.)

${ }^{45}$ Author's translation.
} 
Asked by the interviewer what the motives were for his participation in the 2003 PL campaign song and his defection from PN, Mangion replied that "nothing is possible anymore [referring to the 2008 PN motto] to take place in Malta; we're stuck and have remained stuck" ["M'ghadu xejn possibbli li jsirf'Malta wehlina $u$

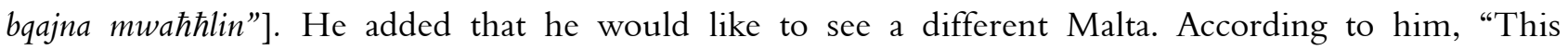
Government is not trusted anymore. It's a government that has exhausted every penny in people's pockets and keeps on saying that Malta is rich; therefore, there's a need for change" ["Ma ghad hemm l-ebda

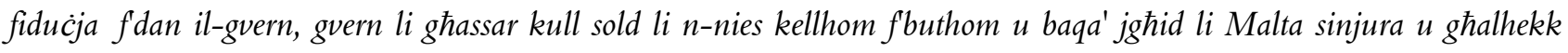
hemm bżonn bidla."]. ${ }^{46}$ Comments such as these, coming from a well-known personality, were a big blow for the PN electoral campaign, especially considering that, five years before, Mangion was strongly supporting their side. In the context of an electoral campaign renowned personalities such as Mangion can become representative, if not the actual voice, of defectors sharing the same sentiments. Mangion's statement could be seen to corroborate what TV viewers were decoding in the absence of singers who had supported the PN in the past but who remained out of view this time.

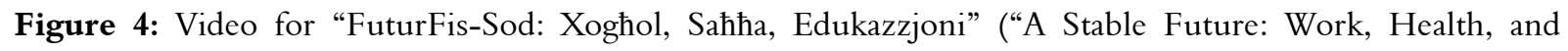
Education")

View at: $\underline{\text { http://dx.doi.org/10.3998/mp.9460447.0010.106 }}$

Figure 5: Video for "Malta Taghna Lkoll" ("Malta for All”)

View at: $\underline{\text { http://dx.doi.org/10.3998/mp.9460447.0010.106 }}$

\section{The Reading of the Individual Singer as Participation}

The uncovering on the part of audiences of what lies behind a performance is in itself a mode of participation. People participate in musical performance by evaluating the presence or, as in the situation described above, the absence of performers, relating that to past events and histories in the singer's life, and on that basis forging both a picture of the present and a prognostication for the future. For informed audiences this challenges and contradicts Theodor Adorno's claim that popular music supports passive listening. Moreover, the presence or absence of an individual singer in performance such as in the situations described above is of utmost importance, as it sheds light on what goes on behind the scenes in the arena of political propaganda and, by extension, in the consciousness of individual singers who both represent and make up the masses. All this begets degrees of participation in which some audience members feel more engaged than others in the decoding process implied and, therefore, feel that in this sense they are more participative than others, even if this is an unconscious process. It is somewhat similar to the situation wherein general listeners feel thrilled as they listen to a musical piece and admire the talent of the composer and performer(s), whereas others are also able to understand what it is about the music (i.e., its structure) that captivates listeners. The latter might feel more immersed in the listening and, therefore, more participative in the process.

The scrutiny of an individual in performance and the level of audience participation in this regard depend on the access that audience members have to the intricate context that surrounds the same

\footnotetext{
${ }^{46}$ Mangion interviewed by $i$ NewsMalta at http://www.inewsmalta.com/dart/20130122-william-mangion-ka-ta-kolloxpossibbli. (Accessed September 10, 2014.)
} 
performance, a context that also takes us on board as listeners. It is a situation that leads one to believe that our understanding of an individual performer's role in musical performance builds on who we are as audience members, how we perceive the world around us, as well as the strategies we adopt to make sense of the flamboyant and unfathomable text that surrounds each performance that individual singers act out and rely on to stage persuasion, truthfulness, desires ${ }^{47}$ and aspirations. It is an entire process strongly shaped by what Thomas Turino refers to as "the internal context of the perceiver," 48 composed of innumerable factors that together ease or constrain such understanding.

Except for the 2013 PL song video described above, the other campaign songs employ a learned musical style that in itself not only builds on the success of past productions but, moreover, keeps the audience focused on the message of the song in which each individual singer is an integral part. In the arena of political propaganda the familiar is more reassuring than the unfamiliar, and this applies to the intertextuality of musical styles, whether they rely on past song videos or on song videos tested in electoral campaigns elsewhere, as with the 2013 Labour song video. The term style refers here both to the pop ballad per se as a vehicle for form and expression and to a whole range of features, activities, and modes of expression, such as the way in which performers are presented, positioned, and marketed. Both aspects were strongly exploited by the PN song videos and, eventually, given a high value for their effectiveness in terms of appeal and persuasion. Starting with the employment of the former aspect, the ballad expands on its potential to focus on the needs and aspirations of each individual listener while at the same time establishing ties sympathetic to other listeners sharing the same feelings and aspirations: "The quintessential ballad ... constructs its listener as special, unique ('I love you')—but within an implicit and comforting awareness of the existence of thousands of other 'yous', suffering the same pangs, desires, frustrations. $" 49$

The singers that move to the fore in the above video songs address listeners individually, as if they know exactly what each listener is feeling and aspiring to. It is a composite message coming from one individual (himself or herself part of the message) to another individual through a very personal mode of communication that accentuates the solidarity of the 'you' in the context of the collective and all the personal exigencies that shape it. This is supported by the wider scenario that makes up the style employed in all three videos, starting from the positioning of the singers in the video and the order in which they appear to the sense of compassion and understanding on each singer's face. It is a style that reinforces the message that "we're all in the same boat," whether you regard us individually or collectively.

The reading of the individual singer as a mode of participation delves deeply into what constitutes the common terrain shared by musicians and politicians. In this regard, John Street asserts that in the domain of music "both musicians and politicians trade in popularity-the creation of an affective community." ${ }^{50}$ In political propaganda the formation of affective communities attests to a strong attempt to "organise people into willing participants of particular ideologies." ${ }^{51}$ However, bringing people in support of an ideological goal presents only one aspect in a long process that requires varied strategies to

\footnotetext{
${ }^{47}$ For a comprehensive discussion on the use of fantasy in popular culture to construct reality and desire, see Slavoj Žižek, "From Reality to the Real," in Cultural Theory and Popular Culture: A Reader, ed. John Storey (Harlow; New York: Pearson Education, 2009), 332-348.

${ }^{48}$ Thomas Turino, Music as Social Life: The Politics of Participation (Chicago: University of Chicago Press, 2008$), 7$.

${ }^{49}$ Richard Middleton, Studying Popular Music (Milton Keynes: Open University Press, 1990), 252.

${ }^{50}$ John Street, "Politics," in Media, Industry and Society, vol. 1 of Continuum Encyclopedia of Popular Music of the World, ed. John Shepherd et al (London: Continuum, 2003), 301.

${ }^{51}$ Peter Webb, Exploring the Networked Worlds of Popular Music: Milieu Cultures (New York: Routledge, 2007$), 148$.
} 
consolidate and eventually sustain the same process. Strategies in this process must be appealing and in continuous balance between the glorious past and the alluring visions of the future. Over time, politicians and political parties have realized the symbolic potential of popular music to convey fashionableness or hipness, and have used pop stars to convey that. ${ }^{52}$ Through their presence in the above song videos, individual singers reinforced the message that "it's cool" to vote in favor of the statements expressed both in song and through their actual presence. Politicians, as Street rightly notes, "find themselves needing to engage with the repertoire of techniques and gestures of popular culture" 53 and pop music provides some of the best means by which this can be achieved. The individual singer negotiates his role within this terrain of popularity trading by, for instance, allowing the politician to exploit the fashionableness with which he or she is endowed in order to attain more mass appeal. Another aspect that may play an important role in this trading scenario is the flexibility that individual singers and musicians might need to accord to politicians on the understanding of what that will eventually render later on. Such flexibility, for instance, may include an endorsement pronounced in speech rather than sung, as with the 2013 Labour video song above.

\section{Conclusion}

Music mediates personal agendas with public political pronouncements. It facilitates the shifting of political allegiances in the prospect of a better future with further opportunities for the defector. The role of individual pop singers in this is multifarious, ranging from their very presence on stage to the lyrics pronounced and the interpretation given to a song, from the positioning they take on stage in relation to others and the surrounding set to the facial gestures and body movements they employ. All this dovetails with the life histories of the singers, any possible conflicts with their own families' political affiliations, and the obligations they owe to the same party from which they distance themselves. In all this, the individuality of the performer emerges as an asset worth manipulating to attract the support of the masses. Music serves as the backdrop within which all this is possible and without which it could not occur. Music and individual musicians are in this sense employed to assist in the deliberate and systematic use of propaganda "to shape perceptions, manipulate cognitions, and direct behaviour to achieve a response that furthers the desired intent of the propagandist."

In the case of Malta, it is through the presence and visibility of local singers that the network of meanings intended to convince the masses can be interlaced, sustained, and expanded upon. The audience is highly active in all this, interpreting both the told and the untold, the musical and the extra-musical, as well as the presence and absence of individual singers whose role becomes central in the creation and propagation of political meanings.

\footnotetext{
52 Street, "Politics," 301.

${ }^{53}$ Ibid., 302.

${ }^{54}$ Garth S. Jowett and Victoria O’Donnell, Propaganda E Persuasion (Thousand Oaks, CA: Sage Publications, 2012 ), 7.
} 


\section{References}

Alexandrova, Ekaterina. "Using Media Effectively: An Analysis of Barack Obama's Election Campaign Aimed at Young Americans." MA thesis, Fordham University, 2010.

Auslander, Philip. "Musical Persona: The Physical Performance of Popular Music." In The Ashgate Research Companion to Popular Musicology, edited by Derek B. Scott, 303-315. Farnham: Ashgate, 2009.

Bartolo, Paul A. Winning People's Hearts: How Social Inclusion and Exclusion Informed the 2013 Malta General Election Campaign. Malta: Malta University Publishing, 2015.

Chetcuti, Kristina. "It's My Party and I'll Sing if I Want To: Election Tunes Rubbished by Music Experts." The Times of Malta, February 28, 2003 . Accessed December 15, 2014. http://www.timesofmalta.com/articles/view/20130228/local/It-s-my-party-and-I-ll-sing-if-I-wantto.459461.

Ciantar, Philip. The Ma'lüf in Contemporary Libya: An Arab Andalusian Musical Tradition. Farnham: Ashgate, 2012.

Denisoff, Serge R. "Folk Music and the American Left: A Generational-Ideological Comparison." The British Journal of Sociology 20, no.4 (December 1969): 427-442. http://dx.doi.org/10.2307/588927.

Dibben, Nicola. "Vocal Performance and the Projection of Emotional Authenticity." In The Ashgate Research Companion to Popular Musicology, edited by Derek B. Scott, 317-333. Farnham: Ashgate, 2009.

Fsadni, Ranier. "The Wounding Song: Honour, Politics and Rhetoric in Maltese Ghana." Journal of Mediterranean Studies 3, no. 2 (1993): 335-353.

Goodwin, Andrew. "Popular Music and Postmodern Theory."Cultural Studies 5, no. 2 (1991): 174-190. http://dx.doi.org/10.1080/09502389100490151.

Grech, Herman. "Singing to Parties' Tunes Creates Dilemma for Performers." The Times of Malta, February 1, 2003. Accessed May 2, 2015.

http://www.timesofmalta.com/articles/view/20030201/local/singing-to-parties-tunes-createsdilemma-for-performers.157713.

Horn, David. "Singer." In Performance and Production, edited by John Shepherd, David Horn, Dave Laing, Paul Oliver and Peter Wicke, 106-112. Vol. 2 of Continuum Encyclopedia of Popular Music of the World. London: Continuum, 2003.

Jowett, Garth S. and Victoria O’Donnell. Propaganda \& Persuasion. Thousand Oaks, CA: Sage Publications, 2012.

Middleton, Richard. Studying Popular Music. Milton Keynes: Open University Press, 1990.

Reljic, Teodor. "The Music of Politics." Malta Today, January 29, 2012. Accessed June 1, 2015. http://www.maltatoday.com.mt/arts/music/15567/the-music-of-politics-20120128\#.U8Vd4ZSSxvk.

Saliba, Joe. "Referendum and General Elections in Malta." In Election Time: The European Yearbook of Political Campaigning 2003, 100-122. Austria: European Association of Political Consultants, 2004.

Street, John. "Politics." In Media, Industry and Society, edited by John Shepherd, David Horn, Dave Laing, Paul Oliver and Peter Wicke, 298-303. Vol. 1 of Continuum Encyclopedia of Popular Music of the World. London: Continuum, 2003.

Turino, Thomas. Music as Social Life: The Politics of Participation. Chicago: University of Chicago Press, 2008.

Vella, Matthew. "IVA Singers Asked to Sing 'No to Europe'," MaltaToday, February 2, 2003, 1.

Vella, Matthew. "What's Noel Gallagher doing with the PN?” MaltaToday, February 10, 2008, 17. 
Webb, Peter. Exploring the Networked Worlds of Popular Music: Milieu Cultures. New York: Routledge, 2007.

Žižek, Slavoj. "From Reality to the Real.” In Cultural Theory and Popular Culture: A Reader, edited by John Storey, 332-348. Harlow; New York: Pearson Education, 2009.

\begin{abstract}
This article examines the role of pop music in Malta as a tool of political propaganda in contemporary electoral campaigning. Renowned local pop singers have played a very important role in this campaigning. Through the analyses of a number of case studies, this paper will argue that the political message lies not only in the music and the lyrics pronounced by these singers but also in their life histories as members of the society to which they address their message. Who these singers are and the political backgrounds that they come from have become part and parcel of a song's meaning. In all this, music mediates personal agendas with public political pronouncements, and the shifting of political allegiances with prospects of a promising future in terms of public exposure and the benefits it entails.
\end{abstract}

